\title{
Study of Liver Function Enzymes i.e. Alanine Amino Transferase, Alkaline Phosphatase in Pre and Post-treated Dogs on Chemotherapy with Doxorubicin and Vincristine in Venereal Granuloma
}

\author{
Anup Yadav', Praveen Kumar ${ }^{2 *}$, Lokesh ${ }^{3}$, Ashwani Kumar ${ }^{2}$, Pankaj Kumar ${ }^{4}$, \\ Rajendra Yadav ${ }^{5}$, N.S. Bugalia ${ }^{1}$ and R.P. Diwakar ${ }^{6}$ \\ ${ }^{1}$ Department of Veterinary Gynaecology and Obstetrics, ${ }^{2}$ Department of Veterinary \\ Medicine, ${ }^{3}$ Department of Veterinary Surgery, ${ }^{4}$ Disease Investigation Laboratory, \\ (LUVAS, Hisar), India \\ ${ }^{5}$ RVDEC, Mahendergarh (LUVAS, Hisar), India \\ ${ }^{6}$ Department of Veterinary Microbiology, C.V.Sc\&A.H., N.D.U.A\&T., \\ Kumarganj, Faizabad (U.P), India \\ *Corresponding author
}

\section{A B S T R A C T}

\section{Keywords}

chemotherapy, Canine

transmissible venereal tumor,

Vincristine and

Doxorubicin

Article Info

Accepted:

07 November 2018

Available Online:

10 December 2018
The present study was carried out in TVCC, Hisar on twenty-four dogs affected with venereal granuloma. Affected dogs were divided equally into three groups viz. vincristine therapy (Group I) with 7 day cycle and doxorubicin therapy consisting two groups i.e. Group II with 14 day cycle and group III with 21 day cycle. Blood sample collection was done at weekly interval and before administration of drug i.e. Day 0, 7, 14 in Group I, Day 0, 7, 14, 21, 28 in Group II and Day 0, 7, 14, 21, 28, 35, 42 in Group III. Biochemical parameters viz. Alanine Amino Transferase, Alkaline Phosphatase was undertaken for study. Significant rise in serum ALP activity recorded in Group I, II, III. Distinct rise in serum ALT observed in Group I and non-significant increasing pattern recorded in Groups II and III.

\section{Introduction}

Venereal Granuloma also known as Canine transmissible venereal tumor (TVT) is a contagious, naturally occurring, horizontally transmitted venereal round cell tumor (Murgia et al., 2006). Transmission of TVT occurs normally by direct contact through coitus by viable tumor cells through injured mucosa and tumour cells are seeded onto mucous membrane but may be transmitted through licking, biting, and sniffing tumor affected areas (Bloom, 1954 and Dass, 1986, Das and Das, 2000). In enzootic areas, where there are high numbers of free-roaming sexually active dogs, TVT is the most common canine tumor (Das and Das, 2000; Ganguly et al., 2016). The lesions of TVT are usually confined to the 
mucous membranes of the external genitalia of dogs of both sexes of any breeds (Amaral $e t$ al., 2004). TVT lesion usually remain localized, but metastasis to the adjacent oral, ocular, nasal, skin and conjunctiva mucosae and inguinal lymph nodes was reported in many cases Chemotherapy with vincristine sulfate is the most frequently used drug and venereal granuloma responds well (Calvet et al., 1982; Cohen, 1985; Johnson, 1994). Other chemotherapeutic agents like cyclophosphamide, vinblastine and methotrexate have also been used alone or in combination (Richardson, 1981; Johnston, 1991; Brown et al., 1981; Yang et al., 1991). Resistant cases can be treated with doxorubicin (Richardson., 1981; Souza et al., 1998). Variation in biochemical parameters viz. ALP, ALT values show increase (due to cytotoxic effect of chemotherapy on liver metabolism).

\section{Materials and Methods}

Twenty four dogs (male and female) with history of bleeding from genital organs were selected. Blood samples were collected from the distal cephalic vein or saphenous vein of male and female dogs from all three groups. Blood samples were collected at weekly interval till $3^{\text {rd }}$ cycle of chemotherapeutic treatment in each group and before administration of drug on the day of treatment. Site of blood collection was shaved and cleaned with antiseptic and5 $\mathrm{ml}$ blood was collected by using 20 and 22 or 24 gauge scalp vein by using 20 and 22 or 24 gauge scalp vein set in plastic centrifugal tube, for serum separation.

Centrifugal tube was kept in slanting position at $4^{\circ} \mathrm{C}$ for $3 \mathrm{hrs}$ and thereafter it was centrifuged at $3000 \mathrm{rpm}$ for ten minutes for serum separation. Thereafter, serum was stored at $-20{ }^{\circ} \mathrm{c}$ until analysed for Liver Function enzymes analysis. Alanine Amino
Transferase (UV kinetic (IFCC) method) and Alkaline Phosphatase (P nitrophenyl phosphate (PNPP).

\section{Results and Discussion}

\section{Serum alkaline phosphatase (ALP)}

Significant rise in serum ALP activity after vincristine therapy (Group I) and distinct increase following doxorubicin regimens (Group II and III) concurs with the reported increase in serum ALP activity following cytotoxic drugs therapy in canine TVT (Kadam et al., 2000 and Cizmeci, 2012).

Recorded increase in ALP activity in TVT dogs evidenced cytotoxic effect of chemotherapy on liver metabolism (Camacho and Laus, 1989; Behera et al., 2012).

\section{Serum alanine amino transferase (ALT)}

Distinct rise in serum ALT on Day 7 posttreatment was followed by marginal increase on Day 14 post-treatment in vincristine treated dogs (Group I). However, serum ALT values during post-treatment period were within the normal range. Present observation in vincristine treated dogs concurs with the reported serum ALT pattern in TVT dogs (Daleck et al., 1987; Camacho and Laus, 1989 and Dinesh et al., 1993).

Serum ALT showed non-significant increasing pattern with marginal drop during the course of doxorubicin therapy in TVT dogs (Groups II and III). Non-significant serum ALT changes following doxorubicin were also reported by Todorovaet al., (2005). However, significant high serum ALT activity after doxorubicin therapy was recorded in TVT dogs (Gadmade, 2006). Elevated ALT values following chemotherapy are consequential to hepatic damage (Behera et al., 2012). 
Table.1 Serum ALP and ALT (Mean \pm SE) in TVT affected dogs during pre and post treatment of vincristine [Group I $(\mathrm{n}=8)$ ]

\begin{tabular}{|l|c|c|c|}
\hline Parameter & DAY0 $\left(\mathbf{1}^{\text {st }}\right.$ dose $)$ & DAY7 $\left(2^{\text {nd }}\right.$ dose $)$ & DAY14 $\left(\left(3^{\text {rd }}\right.\right.$ dose $)$ \\
\hline ALP (IU/L) & $121.57 \pm 0.21^{\mathrm{a}}$ & $122.76 \pm 0.33^{\mathrm{b}}$ & $122.83 \pm 0.49^{\mathrm{b}}$ \\
\hline ALT (IU/L) & $40.73 \pm 0.24$ & $42.57 \pm 0.81$ & $42.71 \pm 0.93$ \\
\hline
\end{tabular}

Day 0-pre-treatment; Days 7 and 14-post treatment

Means with different superscripts $(a, b)$ within a row differ significantly $(p<0.05)$

Table.2 Serum ALP and ALT (Mean \pm SE) of TVT affected dogs during pre and post treatment of doxorubicin [Group II $(\mathrm{n}=8)$ ]

\begin{tabular}{|l|c|c|c|c|c|}
\hline Parameters & DAY0 $\left(\mathbf{1}^{\text {st }}\right.$ dose $)$ & DAY7 & DAY 14 $\left(\mathbf{2}^{\text {nd }}\right.$ dose $)$ & DAY21 & $\begin{array}{c}\text { DAY28 }\left(3^{\text {rd }}\right. \\
\text { dose })\end{array}$ \\
\hline ALP (IU/L) & $93.56 \pm 16.35$ & $94.90 \pm 16.76$ & $94.20 \pm 16.48$ & $94.92 \pm 16.64$ & $94.43 \pm 16.60$ \\
\hline ALT (IU/L) & $31.15 \pm 0.38$ & $32.76 \pm 0.70$ & $31.74 \pm 0.53$ & $32.41 \pm 0.43$ & $31.81 \pm 0.86$ \\
\hline
\end{tabular}

Day 0 - Pre-treatment; Days 7, 14, 21, 28- Post -treatment

Means with different superscripts $(a, b)$ in a row differ significantly $(p<0.05)$

Table.3 Serum ALP and ALT (Mean \pm SE) of TVT affected dogs during pre and post treatment of doxorubicin [Group III $(\mathrm{n}=8)$ ]

\begin{tabular}{|c|c|c|c|c|c|c|c|}
\hline Parameters & $\begin{array}{c}\text { DAYO } \\
\left(1^{\text {st }} \text { dose }\right)\end{array}$ & DAY7 & DAY14 & $\begin{array}{c}\text { DAY21 } \\
\left(2^{\text {nd }} \text { dose }\right)\end{array}$ & DAY28 & DAY35 & $\begin{array}{c}\text { DAY42 } \\
\left(3^{\text {rd }} \text { dose }\right)\end{array}$ \\
\hline ALP (IU/ & $119.43 \pm 0.93$ & $119.58 \pm 0.90$ & $119.01 \pm 0.95$ & $119.54 \pm 0.84$ & $119.80 \pm 0.88$ & $119.79 \pm 1.01$ & $120.42 \pm 0.94$ \\
\hline ALT (IU/L) & $31.85 \pm 0.67$ & $32.90 \pm 0.73$ & $33.05 \pm 0.62$ & $33.23 \pm 0.63$ & $33.42 \pm 0.71$ & $33.83 \pm 0.90$ & $33.71 \pm 0.80$ \\
\hline
\end{tabular}

Figure.1 Histogram showing ALP and ALT (Mean \pm S.E.) in TVT affected dogs (Group I)

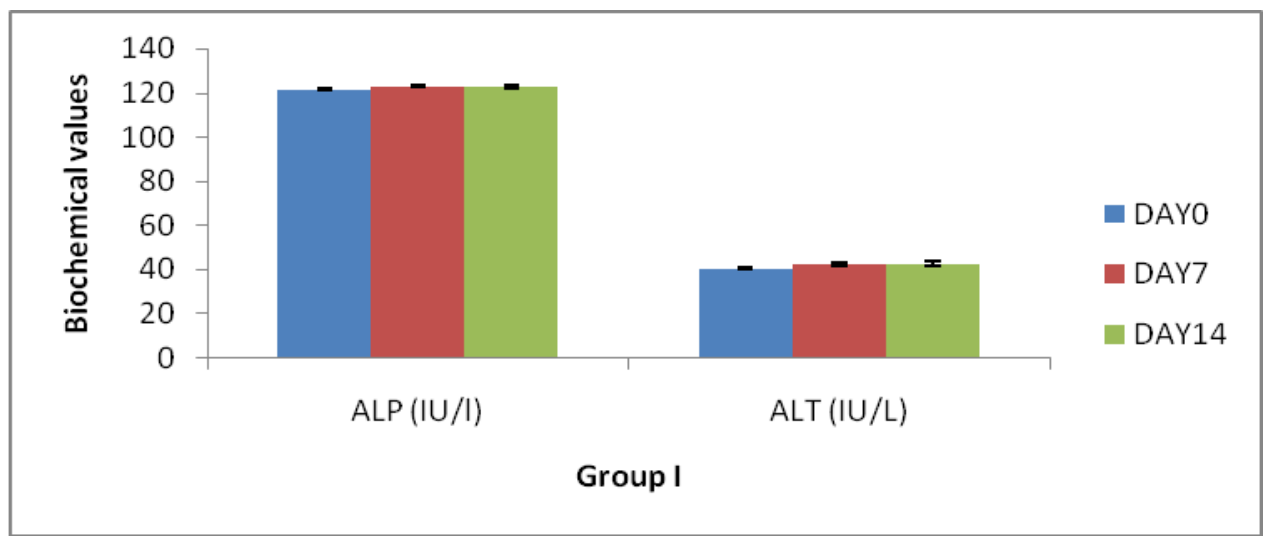


Figure.2 Histogram showing ALP and ALT (Mean \pm S.E.) of TVT affected dogs during pre- and post-treatment of Doxorubicin (Group II)

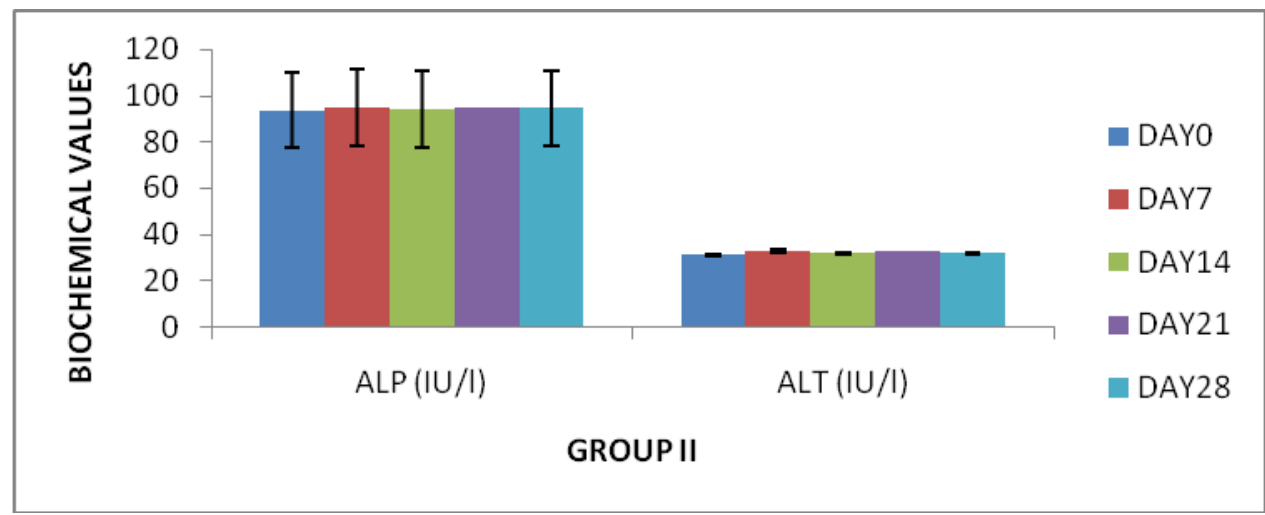

Figure.3 Histogram showing ALP and ALT (Mean \pm S.E.) of TVT affected dogs during pre- and post-treatment of Doxorubicin (Group III)

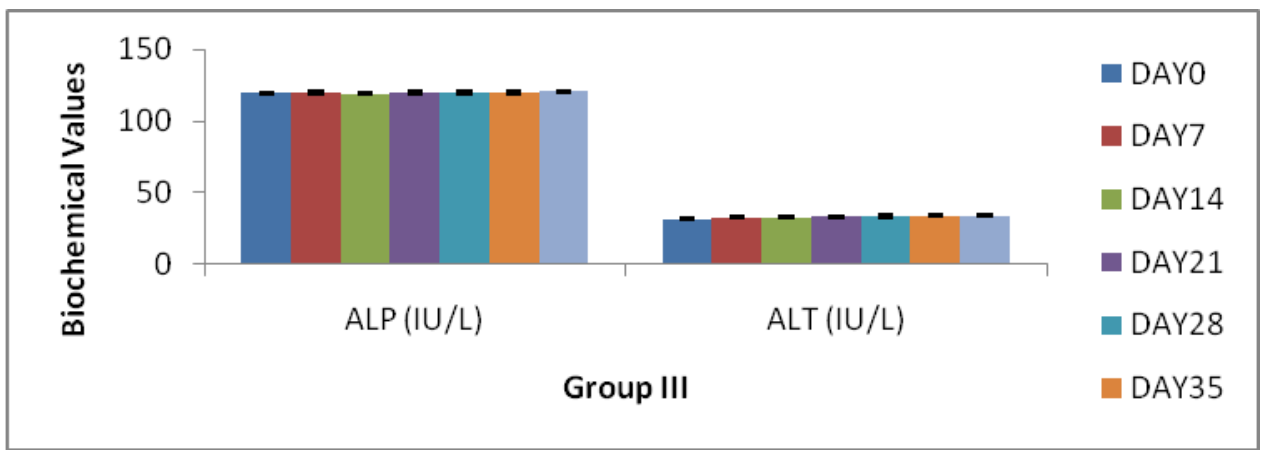

In conclusion, venereal granuloma is a tumour of canines that invariably affects susceptible dogs of both sexes. It is mainly transmitted from infected dog to a susceptible one through coitus. Exact cause of tumour is obscure. There is no specific breed or age relationship with the disease. Although clinical signs and symptoms of disease are indicative of its diagnosis but general elevation of Liver function enzymes viz. ALP and ALT is observed following chemotherapy due to cytotoxic effect of drugs affecting liver metabolism.

\section{References}

Amaral, A.S., Gaspar, L.F.J., Bassani-Silva, S., Rocha, N.S. (2004). Cytological diagnostic of transmissible venereal tumor in the Botucatu region, Brazil (descriptive study: 1994-2003). Rev. Port. Cienc. Vet. 99: 167-171.

Behera, S.K., Kurade N.P., Monsang, S.W., Das, D.P., Mishra, K.K. andMohanta, R.K. (2012). Clinico-pathological fi ndings in a case of canine cutaneous metastatic transmissible venereal tumor. Veterinarski Arhiv 82 (4): 401-410.

Bloom, F. (1954). Pathology of Dog and cat.(American Veterinary Publication Eastern lllinois), 275.

Brown N.O., MacEwen, E.G. and Calvert C.A. (1981). Transmissible venereal tumor in the dog. California Vet.3:6-10.

Calvet, C.A., Leifer, C.E. and McEwen, E.G. (1982). Vincristine for the treatment of Transmissible Venereal Tumor in the dog. J Am Vet Med Assoc.181(2):163-164.

Camacho, A. A., and Laus, J.L. (1989). Study 
of the efficiency of vincristine in the treatment of dogs infected with TVT. Vet. Bull., 59:7.

Cizmeci, S.U., Kose, A.M., Aydin, I., Dinc, D.A., Maden, M and Kose, S.I. (2012). Clinical efficiency of Doxorubicin and Cisplatin in treatment of transmissible venereal tumor of bitches Revue Méd. Vét., 163(11): 516-521.

Cohen D. (1985). The canine transmissible venereal tumor: A unique result of tumor progression. Adv Cancer Res; 43:75-112.

Daleck, C. L. M., Daleck, C. R., Ferreira, H., and Santana, A.E. (1987). New studies on treatment of canine transmisstble venereal tumour(TVT). Ars.Veterinaria, 3: 203209.

Dass, L.L., Sayay, P.N., Khan, A.A., and Jha, G.J., (1986). Malignant transmissible venereal tumour. Canine Practice, 13:1518.

Das, U., and Das, A.K. (2000). Review of canine transmissible venereal sarcoma, Vet. Res. Comm. 24:545-546.

Dinesh, N.M., Rangnath, B.N., Jayadevappa, S.M., and Srinivas, C.L. (1993).Gross and microscopic changes in transmissible venereal tumour following vincristine sulphate therapy. Ind Vet J.70(7):609-611.

Gadmade.(2006). Studies on unusual vaginal tumours in bitches with special Reference in bitches with special reference to therapeutic measures. M.V.Sc. thesis work submitted to Maharashtra Animal \& Fishery.

Ganguly B, Das U and Das A, 2016. Canine transmissible venereal tumour: a review. Vet and comp oncol.14:1-12.

Johnson,C.A.(1994). Infecçõesgenitais e tumor venéreotransmissível. In: Nelson RW, Couto CG, eds. Fundamentos de MedicinaInterna de PequenosAnimais. Rio de Janeiro: Guanabara Koogan; 525.

Johnston S.D. (1991). Performing a complete canine semen evaluation in a small animal hospital. Vet Clin North Am Small AnPract; 21(3):545-551.

Kadam, D.B. (2000). Studies on treatment of venereal granuloma in canine with Reference to submocosal resection and vincristine sulphate therapy M.V Sc. research work submitted to M.A.U. Parbhani.

Murgia, C., Pritchard, J.K., Kim, S.Y., Fassati, A. and Weiss, R.A. (2006).Clonal origin and evolution of a transmissible cancer. Cell, 126: 477-487.

Richardson, R.C. (1981). Canine transmissible venereal tumour. Comp Contin Educ Pract Vet; 3:951-956.

Souza, F.F., de, Tinucci-Costa, M., Faria,Jr, $\mathrm{D}(1998)$. Doxorubicin treatment for recurrent canine transmissible veneral tumor. In: Proceedings of the XXIII Congress of the World Small Anim Vet Assoc. Pp. 772.

Todorova, G., Simeonov, R. and Dinev, D. (2005).Efficacy and toxicity of doxorubicin and cyclophosphamide chemotherapy in dogs with spontaneous mammary tumors. Trakia $j$. of sci..3:5158.

Yang, T.J., Palker, T.J., Harding, M.W. (1991). Tumor size, leukocyte adherence inhibition and serum levels of tumor antigen in dogs with the canine transmissible venereal sarcoma. Cancer Immunol. Immunoth., 33:255-256.

\section{How to cite this article:}

Anup Yadav, Praveen Kumar, Lokesh, Ashwani Kumar, Pankaj Kumar, Rajendra Yadav, N.S. Bugalia and Diwakar, R.P. 2018. Study of Liver Function Enzymes i.e. Alanine Amino Transferase, Alkaline Phosphatase in Pre and Post-treated Dogs on Chemotherapy with Doxorubicin and Vincristine in Venereal Granuloma. Int.J.Curr.Microbiol.App.Sci. 7(12): 735-739. doi: https://doi.org/10.20546/ijcmas.2018.712.090 